\title{
TAM Towards Leddite Building Mandors In The Use Of E-Filing
}

\author{
Permadi Setyo Wibowo Sungkono \\ Faculty of Economic and Bussiness, Airlangga University, Surabaya \\ Email: permadi.setyo.wibowo-2017@feb.unair.ac.id.
}

\begin{abstract}
Abstrak : Tujuan penelitian ini adalah untuk mengetahui persepsi kegunaan, kemudahan serta sikap atas perilaku dalam penggunaan e-filing. Data dari penelitian ini diperoleh melalui kuesioner yang disebarkan terhadap masyarakat dalam golongan gagap teknologi dan telah menghasilkan responden sebanyak 50 orang yang merupakan tenaga kerja mandor bangunan di PT. Hutama Karya (Persero) Cabang Surabaya. Hasil penelitian ini menemukan bahwa variabel persepsi kegunaan serta persepsi kemudahan berpengaruh positif signifikan terhadap penggunaan e-filling., namun variabel sikap pada perilaku ternyata tak memiliki pengaruh dalam penggunaan $e$-filing. Keterbatasan dalam penelitian ini adalah hanya menggunakan 1 perusahaan sebagai sample penelitian, sehingga kurang bisa menggeneralisasi hasil temuan ini.
\end{abstract}

Keywords : Technologi Acceptance Model (TAM), e-filing, WP.

Abstract : This study aims to identify perceptions of usefulness, convenience and attitude towards behavior in the use of e-filling. Data from this study were obtain through quesstionnaires distributed to the community in the category of technological stuttering and had produced 50 respondents consisting of construction foremen in PT. Hutama Karya (Persero) Surabaya Brach. This study had a result that found if the variable perceeived usefullness and perceived easse of being has a possitive and siignificant effecct onthe use of, e-filling, but the attitude towards the most behavior did not affect the use of e-filling. This study hal limitation is that it only uses 1 company as a research sample, so it is less able to generalize these findings.

Keywords: Technology Acceptance Model (TAM), E-filling, Tax Payyer.

\section{INTRODUCTION}

The applicable tax law is the basis and becomes a compulsive levy to the public, but does not have its benefits directly for state financing (Siahaan and SE, 2013). The General Provisions Act and the Taxation procedure explain that tax is a compulsory contribution from individuals or companies or institutions with a forceful nature based on the Law for the continuation of state activities as much as possible for the welfare of citizens who do not receive direct compensation (PR Indonesia, 2009). Generally, most countries in the world require taxation on their citizens, and only a small number decide to make their country's natural resources compared to tax as the country's main income (Pandiangan, 2013). The Minister of Finance of the Republic of Indonesia Sri Mulyani stated that one of the important 
components in revenue (state budget) is tax and is the national backbone, to see the tax contribution in state revenue in the range of 2013 to 2018 along with data on the realization of state revenue from taxes.

Table 1. Realization of State Revenues for the Period of 2013 - 2018 (Billions of Rupiahs)

\begin{tabular}{l|c|c|c|c|c|c}
\hline \multicolumn{1}{c|}{ Source Acceptance } & $\mathbf{2 0 1 3}$ & $\mathbf{2 0 1 4}$ & $\mathbf{2 0 1 5}$ & $\mathbf{2 0 1 6}$ & $\mathbf{2 0 1 7}$ & $\mathbf{2 0 1 8}$ \\
\hline Domestic Revenue & $1.432 .058,60$ & $1.545 .456,30$ & $1.496 .047,33$ & $1.546 .946,60$ & $1.654 .746,10$ & $1.928 .110,00$ \\
\hline Tax Receipts & $1.077 .306,70$ & $1.146 .685,80$ & $1.240 .418,86$ & $1.284 .970,10$ & $1.343 .529,80$ & $1.518 .789,80$ \\
\hline Domestic Tax & $1.029 .850,00$ & 1.103 .217 .60 & $1.205 .479,50$ & $1.249 .499,50$ & $1.304 .316,30$ & $1.472 .908,00$ \\
\hline Income tax & $506.442,80$ & $546.180,90$ & $602.308,13$ & $666.212,40$ & $646.793,50$ & $749,977,00$ \\
\hline value-added tax & $384.713,50$ & $409.181,60$ & $423.710,82$ & $412.213,50$ & $480.724,60$ & $537.267,90$ \\
\hline property tax & $25.304,60$ & $23.476,20$ & $29.250,05$ & $19.443,20$ & $16.770,30$ & $19.444,90$ \\
\hline Land Acquisition Fees & 0 & 0 & 0,30 & 0,50 & 1,20 & 0 \\
\hline Excise Duty & $108.452,00$ & $118.085,50$ & $144.641,30$ & $143.525,00$ & $153.288,10$ & $159.588,60$ \\
\hline Other Taxes & $4.937,10$ & $6.293,40$ & $5.568,30$ & $8.104,90$ & $6.738,50$ & $6.629,50$ \\
\hline International Trade Tax & $47.456,60$ & $43.648,10$ & $34.939,97$ & $35.470,70$ & $39.213,60$ & $45.881,80$ \\
\hline Import duty & $32.621,30$ & $32.319,10$ & $31.212,82$ & $32.472,10$ & $35.066,20$ & $39.116,70$ \\
\hline Export Duty & $15.835,40$ & $11.329,00$ & $3.727,15$ & $2.998,60$ & $4.147,40$ & $6.765,10$ \\
\hline
\end{tabular}

Source: bps.go.id

The table above shows the largest revenue for the country comes from taxes and has increased every year. Along with the increase in state revenue from taxes, taxpayer compliance also increases in reporting tax reports that become a reference in the state revenue reports. The Directorate General of Taxation continues to improve services for taxpayers for convenience and ease in accessing tax reports. Quoting on the page Kompas.com Director of Public Relations P2 Directorate General of Taxes stated there was a 14\% increase in the 2017 Annual Tax Return reporting compared to the previous year (Widiartanto, 2018). The increase in tax reporting rates in 2018 is the result of the government's response to technological developments so that people can carry out tax reporting obligations comfortably (Sesa, 2014).

A major change to the modernization of tax reporting occurred in 2014 when the Director General of Tax (DGT) issued Regulation Per-06 / PJ / 2014 regarding electronic based tax reporting (KKR Indonesia \& Tax, 2014) which required reporting of the VAT and Income Tax Article 21 using the e -filling in the DGT Online site owned by the Directorate General of Taxes. Significant service changes occurred due to the implementation of the regulation, the service that originally required taxpayers to meet face to face in tax reporting, turned into an online service that can be accessed by taxpayers anytime and anywhere. (Ibrahim, 2014) explains that e-filing is a tool issued by the director general of taxation to facilitate the filing process.

E-filing is a digital tax-based Tax Return (SPT) reporting service addressed to both Personal and Entity WPs using digital online and real-time network facilities through a server provided by the application service provider so that it can be accessed fully every day without waiting for a sign receive the manual as before, so it is considered to be very effective and efficient in increasing the comfort of the Taxpayer doing his tax reporting 
obligations. The digital reporting base applied by e-filing is considered beneficial for the government because it can help with online calculations and reduce the amount of incomplete tax data (Tallaha et al., 2014).

A major change to the modernization of tax reporting occurred in 2014 when the Director General of Tax (DGT) issued Regulation Per-06 / PJ / 2014 regarding electronic based tax reporting (Indonesian Review \& Tax Working Paper, 2014) which required reporting of VAT and Article 21 tax returns using e-filling system in the DGT Online's website owned by the Directorate General of Taxes. Significant service changes occurred due to the implementation of the regulation, the service that originally required taxpayers to meet face to face in tax reporting, turned into an online service that can be accessed by taxpayers anytime and anywhere. (Ibrahim, 2014) explained that e-filing is a tool issued by the director general of taxation to facilitate the filing process.

E-filing is a digital tax-based Tax Return (SPT) reporting service addressed to both Personal and Entity WPs using digital online and real-time network facilities through a server provided by the application service provider so that it can be accessed fully every day without waiting for a sign receive the manual as before, so it is considered to be very effective and efficient in increasing the comfort of the Taxpayer doing his tax reporting obligations. The digital reporting base applied by e-filing is considered beneficial for the government because it can help with online calculations and reduce the amount of incomplete tax data (Tallaha et al., 2014).

A major change to the modernization of tax reporting occurred in 2014 when the Director General of Tax (DGT) issued Regulation Per-06 / PJ / 2014 regarding electronic based tax reporting (Indonesian Review \& Tax Working Paper, 2014) which required reporting of VAT and Article 21 tax returns using e-filling system in the DGT Online's website owned by the Directorate General of Taxes. Significant service changes occurred due to the implementation of the regulation, the service that originally required taxpayers to meet face to face in tax reporting, turned into an online service that can be accessed by taxpayers anytime and anywhere. (Ibrahim, 2014) explains that e-filing is a tool issued by the director general of taxation to facilitate the filing process.

E-filing is a digital-based Tax Notification (Annual Notification) reporting service aimed at both private and institutional taxpayers using digital online and real-time network facilities through servers provided by application service providers so that they can be accessed full day without need to wait for a manual receipt as before, so it is considered to be particularly effective and efficient in increasing the comfort of taxpayers doing their tax reporting obligations. The digital reporting base applied by e-filing is considered beneficial for the government because it can help with online calculations and reduce the amount of incomplete tax data (Tallaha et al., 2014).

Taxpayers in Indonesia can be revealed that not fully using e-filing, this is because there is still no socialization from the DGT regarding the use of e-filing that has not been able to reach all taxpayers in Indonesia and taxpayers who cannot follow technological developments in tax reporting. The construction sector in Indonesia is said to be the sector that absorbs the most labor, both highly educated and low educated. The education level of construction workers in Indonesia generally only attains a maximum of 12 years of education as a result of the lack of economic equality in the region and the high cost of education for university levels. The majority of people with a standard education level of 12 years or below work as construction workers and do not keep up with the times, 
especially in the field of technology and lack of interaction using computers. The opinion of taxpayers thinks that reporting an annual notification using the online system will be more difficult than manual reporting which submits physical files directly also plays a big role in the application of e-filling, which in fact the application of e-filling actually benefits both parties in terms of Taxpayers and DGT.

The government has an important role in improving the effectiveness and efficiency of public tax reporting using technology (Chen et al., 2015). According to (Harris and Weistroffer, 2009) stated that user participation is significantly important, in this case taxpayers participate in using e-filing to carry out reporting obligations, DGT may incur huge losses on costs incurred to develop e-filing if in the event of the mandatory the tax is particularly passive in the use of e-filing which can reduce the tax director general's income. A low rate of return will indicate that the information system that has been created and developed by the DGT is ineffective, therefore it is necessary to hold an intensive socialization of the application of e-filling by the DGT.

\section{THEORETICAL REVIEW}

Behavioral Theory in the Application of Information Technology. Previous research (Laudon and Laudon, 2005) proposed a theory based on the theory of behavior that information technology (IT) can change the hierarchy in decisions taken for an institution to use information to reduce costs and expand the distribution of company information. Previous research (Koumbiadis et al., 2014) explained that there was an influence on perceived usefulness in the use of the system for tax compliance, so that taxpayer compliance would be higher if the perceived usefulness perceived by taxpayers was also higher in line with research (Chen et al., 2015) which discusses perceptions about cloud usage. Positions in DGT organizations can be streamlined as a result of the creation and development of e-filling applications. Bosses operating units can receive information directly with the development of information technology systems so as to reduce the position of workers relating to data that has been automatically distributed by the system, and can also in the opposite direction from superiors to the lowest level in the company's organization. In the application of information technology, behavioral aspects have to do with the user's acceptance of information technology currently applied. Technology Acceptance Model (TAM) is a theory that users accept a technology information (IT) and is carried out from the development of models with the aim of analyzing and explaining the factors why people accept the use of information technology (IT).

E-filing. Director General of Taxes Regulation (Indonesian Review Paper \& Tax, 2015) stipulates e-filing is a tax reporting mechanism using digital base electronic channels. The Directorate General of Tax (DGT) developed an online-based tax report to address challenges in the development of the digital world. Information technology is experiencing rapid development nowadays and has been used in various fields such as education (Spitzer, 2014), business (Novickis et al., 2017), construction (Liu and $\mathrm{Hu}, 2017$ ) and health (Krishna, 2017). The reform carried out by the Directorate General of Tax (DGT) in electronic-based reports begins with the registration of new taxpayers (e-registration), routine tax payments (e-billing) and submission of tax reports (e-filing) (Lie and Sadjiarto, 2013) . Technology development in the tax sector has an impact on the application of 
reporting and has the aim to increase the ease and convenience of taxpayers to carry out tax reports and improve efficiency and effectiveness in filing tax files at the Directorate General of Taxes.

Technology Acceptance Model (TAM). Researcher (Davis, 1989) is the person who introduced the TAM theory and in (Laihad, 2013) stated that TAM is a model that uses two variables namely perceived usefulness and perceived ease of use to guess user acceptance towards technology. TAM is considered as one of several theories that are considered significantly effective regarding the use of information technology and is commonly used to seek explanations for individual acceptance of information technology systems. The level of user confidence regarding the use of a particular item that is believed to improve the performance of the user is the definition of perceived usefulness, while the level of user trust associated with a system can be learned and used with is the definition of perceptions of the ease of use.

The purpose of using the TAM theory is to be the basis for understanding external factors that are in the behavior (attitude) and internal beliefs, there are two dominant factors explained by TAM has an influence on the application of technology namely perceptionusefulness --- (usefulness ) and perceived-ease-of-use in using technology (Gangwar et al., 2015). In the implementation of e-filing, the concept of measuring the implementation of egovernment can be carried out using TAM (Santhanamery and Ramayah, 2015). Online and in-time tax reporting is a function of e-filling as a means of taxpayers in carrying out tax reporting obligations.

\section{Hypothesis and Analysis Model.}

\section{Hypothesis.}

Based on the framework above hypothesis in this study are as follows:

H1: Perceived Usefulness has a positive effect on the addition of e-filing users.

$\mathrm{H} 2$ : Perceived-Easy-of-Use has a positive effect on the addition of e-filing users.

H3: Attitude-toward-behavior has a positive effect on the addition of e-filing users. 
Figure 1. Research Framework

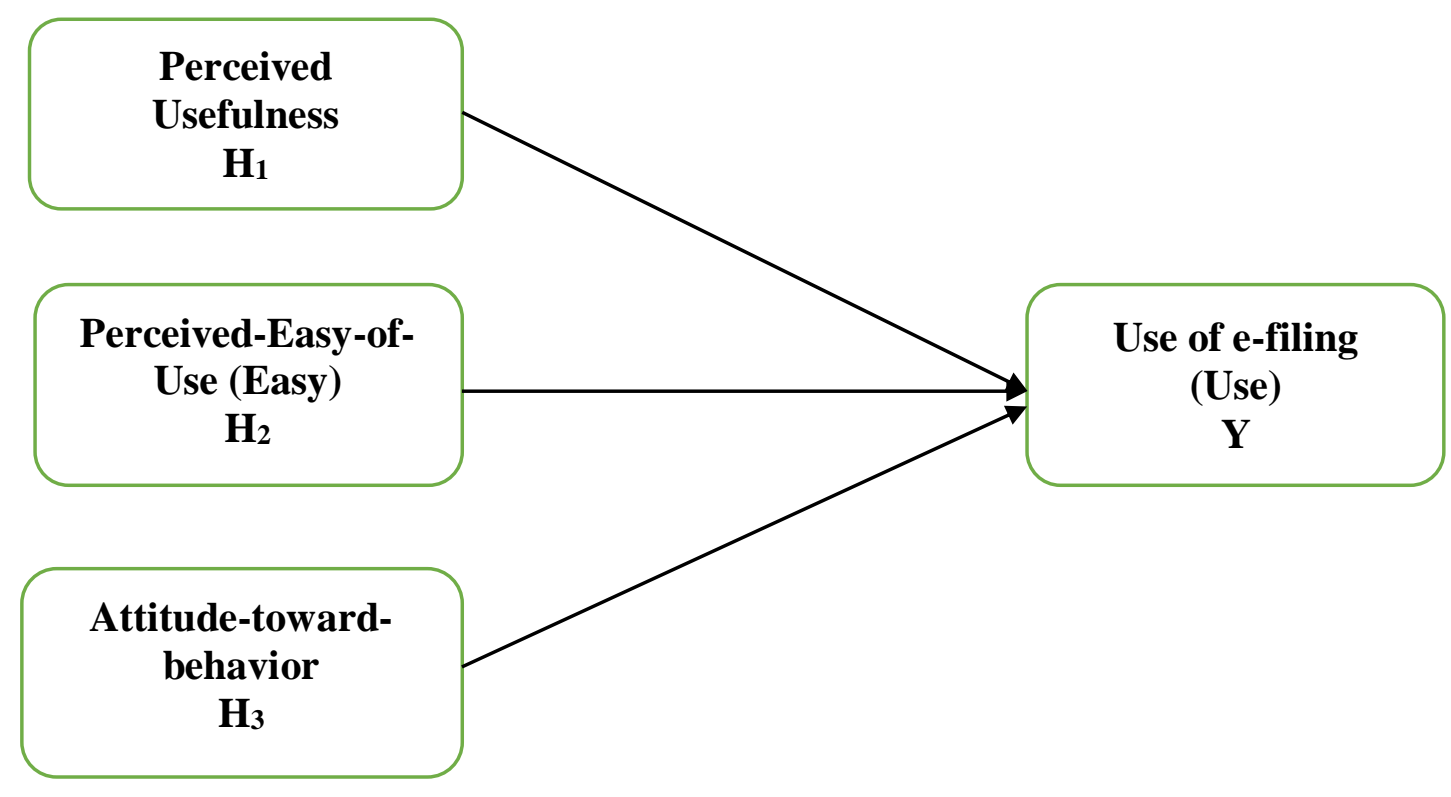

\section{Analysis Model.}

This study uses data analysis to test the hypotheses proposed by researchers in the form of multiple regression models with the following function form:

$$
Y=\alpha+\beta_{1} X_{1}+\beta_{2} X_{2}+\beta_{3} X_{3}+
$$

Information

$\alpha \quad$ : Constants

$\mathrm{X} 1$ : Usability perception

$\mathrm{X} 2$ : Perceived ease

X3 : Attitudes towards behavior

Y : Use of e-filling

$\beta \quad$ : Regression coefficient

\section{METHODOLOGY}

Types of research. The explanatory method used in this study, the variables in this study were processed so that the results appear and clearly explained the relationship between the variables that exist. Primary data were used in the study and were obtained directly from the mandatory building labor tax payers at PT. Hutama Karya (Persero) Surabaya Branch.

\section{Research variable}

Endogenous Variables: Use of e-filing. Primary data is used as a variable for the use of efiling in this study, and comes from questionnaires distributed directly by researchers. The use of e-filing is designated as a form of e-filing application to taxpayers, which is sampled 
by researchers as taxpayers and tax objects and works as a foreman in PT. Hutama Karya (Persero) Surabaya branch and has used e-filing or have never used it directly but know efiling information. A 5-point Likert scale was used in this study to measure the e-filing usage variable. Likert scale points range from 1 to 5 with the provisions of point 1 for the StrongDisagree (SD) choice, point 2 for the Disagree (D) option, point 3 for the Neutral (N) choice, point 4 for the Agree- (A) and the highest point 5 for the Strongly Agree (SA) choice.

1. I feel overall, e-filing can be used easily.

2. I feel bored using e-filing compared to manual reports

3. I can simplify my reporting process by e-filing

Exogenous Variables: Perceived Usefulness. In this study primary data is used as a variable perception of use (Perceived-Usefulness) and comes from questionnaires that are distributed directly by researchers. How individuals interpret the usefulness of the use of a system is a definition of perceived usefulness, such as individuals directly using e-filing because e-filing can be beneficial as well as individuals will hesitate to use e-filing if they do not understand the benefits and trust in the use e-filing. Previous research (Koumbiadis et al., 2014) stated that perceived usefulness influences tax compliance, where the higher perceived usefulness, the higher the compliance and use of e-filing and research on cloud use (Gangwar et al., 2015). The 5-point Likert scale is used by researchers to measure the Perceived-Usefulness variable. Points range from 1 to 5 with a value of 1 for strongly disagree (SD), a value of 2 for disagreeing opinion (D), a value of 3 for a neutral opinion $(\mathrm{N})$, a value of 4 for an agreeing opinion (A) and the last value 5 for opinion Very-Agree(SA).

Researcher's questions related to perceived usefulness are presented as follows:

1. My tax report performance can be improved by using e-filing

2. The effectiveness of my tax returns can be increased by using e-filing

Exogenous Variables: Perception-Convenience. Primary data are used as Perceived-Ease of Use variables and come from questionnaires distributed directly by researchers. Perceived ease (ease-of-use) is defined about how individuals interpret that using and learning the system is easy, user convenience will affect the use of e-filing (Novrinda, 2014). The researcher used a Likert scale to measure the perceived ease of use in this study. There are 5 values in this measurement with a description of value 1 for the Strongly Disagree (SD) option, a value of 2 for the Disagree option (D), a value of 3 for the Neutral option $(\mathrm{N})$, a value of 4 for the Agree (A) option and finally a value of 5 for Very Agree (SA) choice. Below are the types of questions asked by researchers related to perceived ease of the use.

1. I can learn e-filing easily.

2. I can use e-filing easily.

3. I can understand and use e-filing easily.

4. I can adapt easily to e-filing.

5. I can become skilled easily in using e-filing. 
Exogenous Variables: Attitudes towards behavior. Researcher questionnaire is used in this research to produce primary data which is used for Attitude towards Behavior variables. Attitude is the definition of a measure when the user has a positive attitude towards a system that will be used so that the user deigns to use the system. Researcher Teoh, Chong, Lin, \& Chua, (2013) in their research mentioned the user's behavior of a system that as a whole has a specific impact on the factors that determine the individual whether to use a system or not. Likert scale used by researchers in this study with a scale of 1 to 5 in order to measure the variable attitude towards behavior (Attitude Toward Behaviors). Likert scale used with the provisions of a value of 1 for strongly disagree (SD), a value of 2 disagree (D), a value of 3 for a Neutral choice (N), a value of 4 for a choice of Agree (A) and a value of 5 for a choice of Strongly Agree (SA). The types of research questions taken by researchers in this study regarding attitudes towards behavior (Attitude towards Behaviors) are written as follows:

1. I feel comfortable using e-filing.

2. I am happy in using e-filing.

3. I enjoy using e-filing.

Data Collection Method. The method used for data collection in this study uses two methods with the aim of collecting data to a minimum, while the method used is as follows:

1. Develop a questionnaire or list of questions related to the topic in this study.

2. Researchers assist the respondent directly through interviews on the basis of a list of questions that are poorly understood by respondents.

Sampling Method. Researchers determine the sample in this study is an individual taxpayer and works as a foreman in PT. Hutama Karya (Persero) Surabaya Branch. The selection of respondents with these criteria due to the application of e-filing in 2018 has entered the mandatory stage, but for the foremen of buildings with notoriously technological stuttering but have Taxpayer Identification Number whether they can report via e-filing. Convenience Sampling is used as a sampling method in this study, this method gives the researcher the right to choose the sample in accordance with the wishes of the researcher with the aim to facilitate the implementation of research in this study. The reason convenience sampling is used is also because given the number of populations that the researcher will examine is unknown, freedom is needed in determining the sample concisely and quickly.

\section{THE RESULT OF STATISTICAL TESTS}

Questionnaire Return Rate. Researchers determine the population in the study is all taxpayers and tax objects. With the task as a foreman of PT. Hutama Karya (Persero) Surabaya Branch. The chosen sample is taxpayers and tax object and served as building foreman who has used the e-filing tax reporting system or only knows e-filing information and manuals. The method used by researchers to collect samples with the media questionnaire that researchers distribute directly with the Google Form's application to accelerate the collection of research data. When researchers were in the field and interacted directly with the respondents there were several respondents who refused to fill on the 
grounds that they did not understand the topic of e-filling in this study. The following is a questionnaire distribution table for the respondents who have received the questionnaire.

Table 2. Distribution Questionnaire

\begin{tabular}{|l|c|}
\hline \multicolumn{1}{|c|}{ Information } & Questionnaire Number \\
\hline The total questionnaire was distributed & 57 \\
\hline $\begin{array}{l}\text { Amount that can be processed } \\
\text { Amount that cannot be processed } \\
\text { Amount that cannot be returned }\end{array}$ & 50 \\
\hline Final sample observation & 7 \\
\hline
\end{tabular}

Data Source: Primary data processing results

Of the 57 questionnaires distributed, $100 \%$ of the questionnaires returned because they used the Google form application to facilitate the search for respondents. Of all the returned questionnaires, only 50 could be processed while 7 could not be processed further because there was an incomplete identity included in the questionnaire and there were questions in the questionnaire that had not been answered.

Profile of Respondents. The following presents the profile of the latest education and the age of the respondents presented in graphical form.

Figure 2. Characteristics of respondents by age.

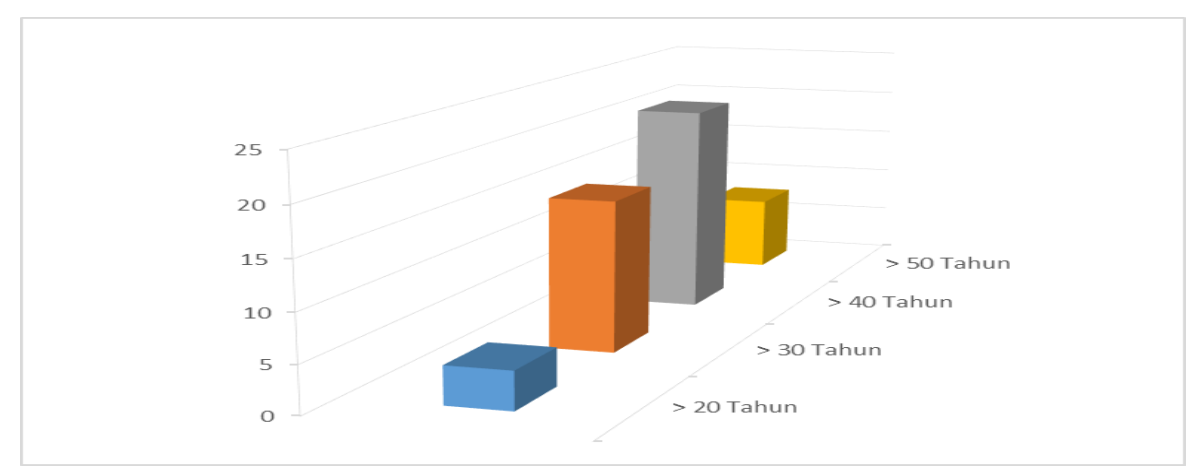

The graph above explains that the age profile of respondents in this study aged over 20 years was 4 respondents (8\%), over 30 years as many as 16 people (32\%), over 40 years as many as 22 people (44\%) and those over 50 years old as many as 8 people (16\%). 
Figure 3. Characteristics of respondents based on education

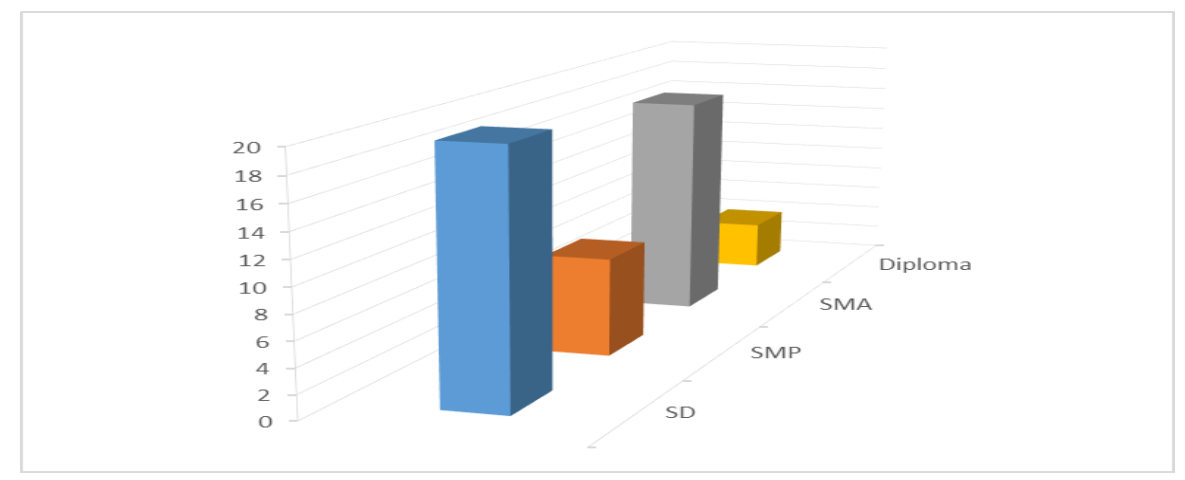

The graph explained that the age profile of respondents in this study with elementary education was 20 respondents (40\%), junior high school students were 8 people (16\%), high school students were 18 people (36\%) and Diploma were 4 people (8\%). Educational profiles can also determine an individual's level of knowledge of technology, both formally and each individual's experience.

Table 2 shows the ways and standard deviations of responses to items that measure usage, perceived usefulness, convenience and behavior.

Table 3. Average and standard deviations of the study items

\begin{tabular}{lcc}
\hline \multicolumn{1}{c}{ Items } & $\begin{array}{c}\text { Mean } \\
\text { Value }\end{array}$ & SD \\
\hline \multicolumn{1}{c}{ Use of e-filing } & & \\
\hline I feel the whole e-filing can be used easily & 4,22 & 0,51 \\
\hline I feel bored using e-filing compared to manual reports & 2,34 & 1,17 \\
\hline I can simplify my reporting process by e-filing & 4,32 & 0,55 \\
\hline \multicolumn{1}{c}{ Perceived Usefulness } & \\
\hline My tax report performance can be improved by using e-filing & 4,04 & 0,78 \\
\hline $\begin{array}{l}\text { The effectiveness of my tax returns can be improved by using } \\
\text { e-filing }\end{array}$ & 4,04 & 0,64 \\
\hline Perceived Ease of Use Perception & 3,98 & 0,74 \\
\hline I can learn e-filing easily & 4,02 & 0,77 \\
\hline I can understand and clearly use e-filing easily & 4,00 & 0,76 \\
\hline I can adapt easily to e-filing & 4,16 & 0,55 \\
\hline I can easily become skilled in using e-filing & 3,80 & 0,83 \\
\hline
\end{tabular}

Attitude Towards Behaviors 


\begin{tabular}{lrc}
\hline I feel comfortable using e-filling & 4,00 & 0,83 \\
\hline I feel happy using e-filling & 4,18 & 0,63 \\
\hline I enjoy using e-filing & 4,04 & 0,73
\end{tabular}

Data source: Primary data processed

In this study the reliability test was carried out through a method by looking at the results of the Cronbach Alpha values in the table below.

Table 4. Reliability Test

\begin{tabular}{l|c}
\hline \multicolumn{1}{c|}{ Variables } & Cronbach Alpha \\
\hline Perceived Usefulness: X1 & 0.683 \\
Perceives Ease of Use: X2 & 0.954 \\
Attitude Towards Behavior X3 & 0.921 \\
Use ᄀe-filling: Y & -0.200 \\
\hline
\end{tabular}

Data source: Primary data processed

Cronbach Alpha can be a reference value from the reliability of a research construct. According to Ghozali, (2011) in (Setiawan, Kurniawan, \& Payamta, 2018) stated that Cronbach Alpha with a value showing above 0.60 can be stated to be reliable, where in table 4 above it appears that almost all independent variables that have been tested for reliability produce values above 0.60 so that it can be said that the variable is reliable.

Hypothesis test. Testing the hypothesis proposed by researchers in this study using the Structural Equation Model (SEM) model using the Partial Least Square (PLS) model analyst. The researcher uses the Windows version of Warp PLS 5.0 application in this study to conduct a PLS analysis test with the aim of examining the application of TAM in the application of e-filing systems.

Table 5. AVE and Composite Reliability Point

\begin{tabular}{l|c|c|c}
\hline \multicolumn{1}{c|}{ Variables } & AVE & $\begin{array}{c}\text { Composite } \\
\text { Realibility }\end{array}$ & Conclusion \\
\hline e-filling.Use (USE) & 0.645 & 0.476 & Significant \\
\hline Perception of Use (USEFULNESS) & 0.759 & 0.863 & Significant \\
\hline Attitudes towards behavior (EASE) & 0.847 & 0.965 & Significant \\
\hline Use of E-filing (ATTITUDE) & 0.864 & 0.950 & Significant \\
\hline
\end{tabular}

Discriminant validity measurement is a measurement method that uses a way to compare the results of the Square Root Average (AVE) value of the existing construct to the correlation with other constructs in the model presented in the results of the PLS analysis as set out in the table above. The recommended AVE value must have a value above the 0.5 value, in table 5 presented above the AVE value generated by each of the variables in this 
study has a value above 0.5 so that these results conclude the independent variables used in this study are valid and can be trusted for reliability.

Table 6. Path coefficients and $\mathrm{P}$ values

\begin{tabular}{l|l|l}
\hline \multicolumn{1}{c|}{ Path } & Path Coefficient & P-Value \\
\hline USEFULNESS $\longrightarrow$ USE & 0.148 & 0.191 \\
\hline EASE $\longrightarrow$ USE & 0.381 & 0.008 \\
\hline ATTITUDE $\longrightarrow$ USE & 0.420 & 0.004 \\
\hline
\end{tabular}

Based on the results in table 6 , the researcher can conclude that the Perceived Usefulness variable has a positive influence on the use of the Taxpayer e-filing system. This conclusion is reflected based on the P-Value of 0.191, where the resulting value is greater than the value of 0.05 . Based on the estimated value of the regression coefficient (path coefficient) produced, which is equal to 0.148. Regression coefficient which showed a positive value means that there is a direct relationship between the perception of usefulness (Perceived Usefulness) on the use of e-filing, where if the perception of usefulness increases by 1 time, the quality of the data system also has increased by 0.148 times, so it can be concluded that the first hypothesis proposed by researchers in this study is accepted where the variable perception of usefulness has a positive influence on the use of taxpayer's efiling in Indonesia. This test released a result which stated that the higher the perception of usefulness received by tax payers, the more tax reporting would be carried out with the use of e-filing in Indonesia. Taxpayers will be able to better understand the uses and advantages of e-filing and receive benefits by using e-filing so that they can be more obedient to tax regulations. The steps taken by the government in developing information technology through e-filing can be said to be successful if taxpayers have a clear understanding of changing tax reporting, from initially using a manual system to switching to an online system. Previous studies (Chen et al., 2015; Koumbiadis et al., 2014; Lean et al., 2009; Saad and Haniffa, 2014) have the same results as current research by stating that perceptions of usefulness have positive effects for public compliance with reporting tax obligations.

As for the variable Perceived ease of use significantly positive effect on the use of efiling. This can be seen from the p-values of 0.008. Based on the estimated value of the regression coefficient (path coefficient) produced showed the value of 0.381 . The positive sign on the regression coefficient explained that there is a direct relationship between the Perceived ease to uses to the use of e-filing, where if the user's expertise also increases 1 time, then the quality of the system data will increase by 0.381 times. It can be concluded that the second hypothesis of perceived ease of use variables appears to have a significant positive effect on taxpayers' e-filing usage and is in line with the expectations of the TAM theory from (Davis, 1989); (Laihad, 2013) explaining if perceived ease is one of the important indicators when adopting a technology (Dorasamy, 2012); (Faaeq, 2013); (Tallaha et al., 2014). Taxpayers will have a tendency to be more compliant with taxation if the taxpayer has the notion that the e-filing system is an easy system to understand and use. Tax payer that has the notion that e-filing can be easily used and understood can be a benchmark of socialization that has been carried out by the government in implementing efiling for taxpayers. 
In line with (Liang and $\mathrm{Lu}, 2013$ ) the hypothesis that has been tested yields results if the desire to use e-filing will increase if individuals or taxpayers consider e-filing easy to understand. The Directorate General of Taxes should be given clear and sufficient information to taxpayers regarding the online e-filing tax reporting system, so that they have adequate knowledge about it. The researchers (Shao et al., 2015) in an earlier study in China also showed the ease of understanding online tax has a positive influence on interest in using the online tax system.

Attitude towards behavior does not significantly influence the use of e-filing applications by taxpayers. (Teoh et al., 2013) in his research mentions user behavior over a system that as a whole has a specific impact on the factors that determine the individual whether to use a system or not. However, the current study found no significant effect of attitudes towards behavior on the use of e-filing applications of taxpayers. This is reflected in the p-values that produce 0.004 result where the value is smaller than 0.05 . From the results of estimation of the regression coefficient (path coefficient), the resulting coefficient is 0.420 . Regression coefficient which has a positive sign means that there is a one-way relationship between attitudes towards behavior for the use of e-filing which if the user's behavior rises 1 time so that the quality of the system data also increases by 0.420 times. It can be concluded that the third hypothesis of attitudes towards behavior does not have a significant positive effect on the use of taxpayers e-filing. The attitude of the tax that has no influence in the use of e-filing becomes an opportunity for new research. Attitudes of taxpayers who might be stated to be ambiguous because they feel they have concerns if they do tax reporting online or even report their tax statements as they are. Indications of educational background can also be influenced by the attitude of taxpayers towards the use of e-filing which generally the lower the education taken by a person, the lower the response will be to technological progress.

Figure 4. Result of Structural Equation Model (SEM)

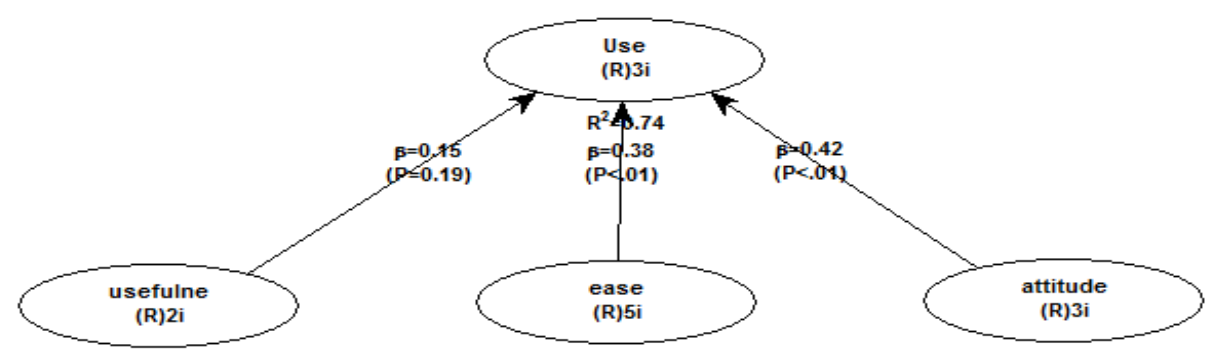

\section{DISCUSSION}

The result of hypothesis one (H1) tested explain that perceived usefulness has a significant influence on the use of taxpayer e-filing applications. Basically, the implementation of a new system in tax reporting is a new breakthrough to ease the burden of taxpayers. So even in using the system, taxpayers must be able to take responsibility and not consider e-filling reporting as a burden. Therefore, perceived usefulness has a significant positive effect on the use of taxpayer's e-filing so that the first hypothesis (H1) is accepted. Basically, changing the manual reporting system to an electronic system is a big investment 
to increase the level of public compliance, so that the electronic system is made to increase efficiency and effectiveness (Alsabawy, 2016) confirms that the perception of usability is the main factor determining a successful system to be implemented, the perception of usability is also the cause of the community still using an electronic system, especially in the service sector (Baker-Eveleth and Stone, 2015). According to (Abbas and Hamdy, 2015) who found that perceived usefulness is particularly closely related to the increased use of information technology, so that the system implemented is used in the long term.

The second hypothesis (H2) which states the perception of ease has a significant positive effect on the use of e-filing. This study showed the result that with the perception of ease in filling e-filing will increase the use of e-filling because it helps taxpayers in reporting their tax reports. Researchers (Mohammadi et al., 2017) revealed that the perception of ease is a factor that must be possessed by an electronic system, and those factors that determine a successful system to be integrated (Hsieh and Cho, 2011; Hussein et al., 2007; Johnson et al., 2008; Joo et al., 2011; Lee, 2009; Limayem and Cheung, 2008). People who have the perception of ease of an electronic system, will tend to use the system in a longer period (Chiu and Wang, 2008). This implies that, if users find e-filing services to be useful and increase their interaction with government agencies, then they will be more likely to continue to use these services. Therefore, the designer must take into account the needs of users in designing e-government systems (Noor et al., 2016).

The third hypothesis (H3) proposed explains that attitudes toward behavior do not have a positive influence on the use of e-filing. This stated that the value of the attitude variable towards behavior has no impact on the increasing use of e-filing variables, on the test result it can be concluded the value of the attitude variable toward behavior has no impact on the increase in value of the variable using e-filing so that the third hypothesis $\mathrm{H} 3$ is rejected. Attitudes towards community behavior do not change even though the system used changes to e-filing, this can be due to the low desire of the community to use the new system (Zhao et al., 2015). The low attitude towards community behavior towards the use of e-filing can be an indication that e-filing is less informative and less credible in the eyes of the community (Zhao et al., 2015). The negative influence of attitudes on behavior towards the use of e-filing can also be caused by public perceptions that government and community interactions regarding e-filing are less satisfying (Oni, et al., 2016).

\section{CONCLUSION}

This study was conducted with the aim to find out how the use of e-filing is influenced by perceived usefulness, perceived ease and attitude toward behavior. In this study we found positive results on the perception of usefulness and perceived ease of use of e-filing. So it can be said with the ease and intention to use e-filing, it will increase the use of e-filling systems. As for attitudes toward behavior has an influence in the use of e-filing.

Limitations in this study are only using 1 company as a research sample, so it is less able to generalize these findings. Therefore, further research can use more than one company so that the results obtained are more relevant. 


\section{REFERENCES}

Abbas, H. A., and Hamdy, H. I. (2015). Determinants of Continuance Intention Factor in Kuwait Communication Market: Case study of Zain-Kuwait. Computers in Human Behavior, 49, 648-657.

Alsabawy, A. Y., Cater-Steel, A., and Soar, J. (2016). Determinants of Perceived Usefulness of E-learning Systems. Computers in Human Behavior, 64, 843-858.

Baker-Eveleth, L., and Stone, R. W. (2015). Usability, Expectation, Confirmation, and Continuance Intentions to Use Electronic Textbooks. Behaviour \& Information Technology, 34(10), 992-1004.

Chen, J. V., Jubilado, R. J. M., Capistrano, E. P. S., and Yen, D. C. (2015). Factors Affecting Online Tax Filing-An Application of The IS Success Model and Trust Theory. Computers in Human Behavior, 43, 251-262.

Chiu, C.-M., and Wang, E. T. (2008). Understanding Web-based Learning Continuance Intention: The Role of Subjective Task Value. Information \& management, 45(3), 194-201.

Davis, F. D. (1989). Perceived Usefulness, Perceived Ease of Use, and User Acceptance of Information Technology. MIS quarterly, 319-340.

Dorasamy, M., Marimuthu, M., Raman, M., and Kaliannan, M. (2012). E-Government Services Online: An Exploratory Study on Tax E-filing in Malaysia Technology Enabled Transformation of the Public Sector: Advances in E-Government (pp. 312325): IGI Global.

Faaeq, M. K., Ismail, N. A., Osman, W. R. S., Al-Swidi, A. K., and Faieq, A. K. (2013). A Meta-Analysis of The Unified Theory of Acceptance and Use of Technology Studies Among Several Countries. Electronic Government, an International Journal, 10(3-4), 343-360.

Gangwar, H., Date, H., and Ramaswamy, R. (2015). Understanding Determinants of Cloud Computing Adoption Using an Integrated TAM-TOE Model. Journal of enterprise information management.

Ghozali, I. (2011). Aplikasi Analisis Multivariate Dengan Program IBM: Spss.

Harris, M. A., and Weistroffer, H. R. (2009). A New Look At The Relationship Between User Involvement In Systems Development and System Success. Communications of the Association for Information Systems, 24(1), 42.

Hsieh, P.-A. J., and Cho, V. (2011). Comparing e-Learning Tools' Success: The Case of Instructor-Student Interactive vs. Self-Paced Tools. Computers \& education, 57(3), 2025-2038.

Hussein, R., Karim, N. S. A., and Selamat, M. H. (2007). The Impact of Technological Factors on Information Systems Success In The Electronic-Government Context. Business Process Management Journal.

Ibrahim, I. (2014). The Compliance Time Costs of Malaysian Personal Income Tax System: E-filers vs. Manual-Filers. Procedia-Social and Behavioral Sciences, 164, 522-527.

Peraturan Direktorat Jenderal Pajak Nomor PER-06/PJ/2014 tentang Tata Cara Penyampaian Surat Pemberitahuan Tahunan Bagi Wajib Pajak Orang Pribadi Yang Menggunakan Formulir 1770S atau 1770SS Secara e-Filing dan Merupakan Pegawai Tetap Pada Pemberi Kerja Tertentu, (2014). 
Peraturan Direktorat Jenderal Pajak Nomor PER-03/PJ/2015 Penyampaian Surat Pemberitahuan Elektronik, (2015).

Indonesia, P. R. (2009). Undang-Undang Republik Indonesia Nomor 16 TAHUN 2000. Available in: http://peraturan. go. id/uu/nomor-10-tahun-2009. html [accessed on 21 March 2016].

Johnson, R. D., Hornik, S., and Salas, E. (2008). An Empirical Examination of Factors Contributing to The Creation of Successful E-learning Environments. International Journal of Human-Computer Studies, 66(5), 356-369.

Joo, Y. J., Lim, K. Y., and Kim, E. K. (2011). Online University Students' Satisfaction and Persistence: Examining Perceived Level of Presence, Usefulness and Ease of Use As Predictors In a Structural Model. Computers \& education, 7(2), 1654-1664.

Koumbiadis, N., Okpara, J. O., Pandit, G. M., and Ritsatos, T. (2014). Tax Evasion and Compliance; From The Neo Classical Paradigm to Behavioural Economics, A Review. Journal of Accounting \& Organizational Change.

Krishna, R. (2017). The Impact of Health Information Technology on The Doctor-Patient Relationship in Child and Adolescent Psychiatry. Child and Adolescent Psychiatric Clinics, 26(1), 67-75.

Laihad, R. C. (2013). Pengaruh Perilaku Wajib Pajak terhadap Penggunaan E-Filing Wajib Pajak di Kota Manado. Jurnal EMBA: Jurnal Riset Ekonomi, Manajemen, Bisnis dan Akuntansi, 1(3).

Laudon, K. C., dan Laudon, J. P. (2005). Sistem Informasi Manajemen Mengelola Perusahaan Digital. Edisi VIII. Andi. Yogyakarta.

Lean, O. K., Zailani, S., Ramayah, T., and Fernando, Y. (2009). Factors Influencing Intention to Use E-government Services Among Citizens in Malaysia. International Journal of Information Management, 29(6), 458-475.

Lee, M.-C. (2009). Factors Influencing The Adoption of Internet Banking: An Integration of TAM and TPB With Perceived Risk and Perceived Benefit. Electronic commerce research and applications, 8(3), 130-141.

Liang, S. w., and Lu, H. p. (2013). Adoption of E-government Services: An Empirical Study of The Online Tax Filing System in Taiwan. Online Information Review.

Lie, I., and Sadjiarto, R. A. (2013). Faktor-Faktor Yang Mempengaruhi Minat Perilaku Wajib Pajak Untuk Menggunakan e-Filing. Tax \& Accounting Review, 3(2), 147.

Limayem, M., and Cheung, C. M. (2008). Understanding Information Systems Continuance: The Case of Internet-Based Learning Technologies. Information \& management, 45(4), 227-232.

Liu, J., and Hu, C.-Z. (2017). Application of Information Technology in Active Safety Control for Construction Machine. Procedia engineering, 174, 1182-1189.

Mohammadi, F., Abrizah, A., and Nazari, M. (2017). Is The Information Fit For Use? Exploring Teachers Perceived Information Quality Indicators For Farsi Web-Based Learning Resources. Malaysian Journal of Library \& Information Science, 20(1).

Noor, N. L. M., Harun, A. F., Adnan, W. A. W., Saman, F. M., and Noh, M. A. M. (2016). Towards The Conceptualization of Citizen User Experience: Citizens' Preference for Emotional Design in E-Government Portal. Paper presented at the 2016 4th International Conference on User Science and Engineering (i-USEr). 
Novickis, L., Mitasiunas, A., and Ponomarenko, V. (2017). Information Technology Transfer Model as a Bridge Between Science and Business Sector. Procedia Computer Science, 104, 120-126.

Novrinda, I. (2014). Pengaruh Persepsi Wajib Pajak Orang Pribadi Terhadap Penggunaan Electronic Filing (E-Filing) Di KPP Pratama Palembang Ilir Barat. Politeknik Negeri Sriwijaya.

Oni, A. A., Adewoye, O. J., and Eweoya, I. O. (2016). E-banking Users' Behaviour: Eservice Quality, Attitude, and Customer Satisfaction. International Journal of Bank Marketing.

Pandiangan, L. (2013). Modernisasi dan Reformasi Pelayanan Perpajakan: Elex Media Komputindo.

Saad, R. A. J., and Haniffa, R. (2014). Determinants of Zakah (Islamic tax) Compliance Behavior. Journal of Islamic Accounting and Business Research.

Santhanamery, T., and Ramayah, T. (2015). Understanding The Effect of Demographic and Personality Traits on The E-filing Continuance Usage Intention in Malaysia. Global Business Review, 16(1), 1-20.

Sesa, E. S. (2014). Pengaruh Persepsi Wajib Pajak Orang Pribadi Pada Penerapan eFiling Terhadap Kepatuhan Dalam Menyampaikan SPT Tahunan di Kota Surabaya. Universitas Pelita Harapan Surabaya-Faculty Of Business School-Department Of.

Setiawan, D., Kurniawan, B., dan Payamta, P. (2018). Dampak penggunaan e-filling terhadap kepatuhan wajib pajak: peran perilaku wajib pajak sebagai variabel mediasi. Jurnal Akuntansi dan Auditing Indonesia, 22(1), 12-24.

Shao, B., Luo, X., and Liao, Q. (2015). Factors Influencing E-tax Filing Adoption Intention By Business Users in China. Electronic Government, an International Journal, 11(4), 283-305.

Siahaan, M. P., dan SE, M. (2013). Pajak Daerah \& Retribusi Daerah: Berdasarkan UndangUndang Nomor 28 Tahun 2009 tentang Pajak Daerah dan Retribusi Daerah. Jakarta: Rajawali Pers.

Spitzer, M. (2014). Information Technology In Education: Risks and Side Effects. Trends in Neuroscience and Education, 3(3-4), 81-85.

Tallaha, A. M., Shukor, Z. A., and Hassan, N. S. A. (2014). Factors Influencing E-Filing Usage Among Malaysian Taxpayers: Does Tax Knowledge Matters? Jurnal Pengurusan (UKM Journal of Management), 40.

Teoh, W. M. Y., Chong, S. C., Lin, B., and Chua, J. W. (2013). Factors Affecting Consumers' Perception of Electronic Payment: An Empirical Analysis. Internet Research.

Widiartanto, Y. H. (2018). 10,59 Juta SPT Masuk, 80 Persen Melalui E-Filing. Retrieved from https://ekonomi.kompas.com/read/2018/04/02/101100226/10-59-juta-sptmasuk-80-persen-melalui-e-filing.

Zhao, J., Chi, M., Zhu, Z., and Hu, L. (2015). From Digital Business Strategy to E-business Value Creation: a Three-Stage Process Model. International Journal of Networking and Virtual Organisations, 15(2-3), 215-241. 